doi: $10.2306 /$ scienceasia1513-1874.2013.39.124

\title{
Authentication of the Thai medicinal plants sharing the same common name 'Rang Chuet': Thunbergia laurifolia, Crotalaria spectabilis, and Curcuma aff. amada by combined techniques of TLC, PCR-RFLP fingerprints, and antioxidant activities
}

\author{
Pipob Suwanchaikasem, Thatree Phadungcharoen, Suchada Sukrong* \\ Department of Pharmacognosy and Pharmaceutical Botany, Faculty of Pharmaceutical Sciences, \\ Chulalongkorn University, Bangkok 10330 Thailand \\ *Corresponding author, e-mail: suchada.su@chula.ac.th
}

Received 23 Jul 2012

Accepted 27 Feb 2013

\begin{abstract}
The herbal drug known as 'Rang Chuet' has been widely used in traditional Thai medicine for the treatment of poisoning. However, at least three medicinal plants, Thunbergia laurifolia, Crotalaria spectabilis, and Curcuma aff. amada, share this name. Because of the similarity in nomenclature, the commercial products are considered authentic and have been effectively used as herbal drugs. Therefore, the aims of this study were to compare the biological activities of these plants with antioxidant assays and to establish a reliable method to identify the original plant species. T. laurifolia exhibited the highest free-radical-scavenging and ferric-reducing properties of the three aqueous extracts. Crotalaria spectabilis exhibited the highest antioxidant activity when ethanolic extracts were investigated. The total phenolic content was associated with the antioxidant capacities of the extracts. Thin-layer chromatography (TLC) and polymerase chain reaction-restriction fragment length polymorphism (PCR-RFLP) methods were used to differentiate the three species. In the TLC analysis, characteristics of flavonoids in the ethanolic extracts and of phenolic compounds in the aqueous extracts were observed for T. laurifolia and Crotalaria spectabilis but not for Curcuma aff. amada. Variable sites in the matK genes of the three species were identified and can be recognized by the restriction enzymes DdeI and HaeIII. In summary, the TLC and PCR-RFLP fingerprints established in this study can be used to discriminate between T. laurifolia, Crotalaria spectabilis, and Curcuma aff. amada. As 'Rang Chuet' samples from different plant origins differ in their antioxidant potency, the substitution of these medicinal plants should be recognized.
\end{abstract}

KEYWORDS: species differentiation, DNA fingerprinting, matK gene, antioxidant activity

\section{INTRODUCTION}

'Rang Chuet' is the Thai vernacular name of several medicinal plants belonging to different families. The best known and most commonly used species, Thunbergia laurifolia Lindl., is a woody climbing plant of the Acanthaceae family. In a number of previous studies, T. laurifolia was observed to have detoxifying effects against insecticides, ethyl alcohol, and metallic poisons as well as in the treatment of drug addiction ${ }^{1-6}$. This species has also been reported to have anti-inflammatory, anti-diabetic, and antipyretic properties ${ }^{7}$. Crotalaria spectabilis Roth (Fabaceae) and Curcuma aff. amada Roxb. (Zingiberaceae) are also known as 'Rang Chuet'. The specific species name of the Curcuma aff. amada plant has not yet been assigned, however, it appears to have an affinity with
Curcuma amada. The rhizome of Curcuma aff. amada contains white-coloured material, which differs from the yellow colour of turmeric $(C$. longa L.). Traditionally, the leaves and roots of Crotalaria spectabilis and the rhizomes of Curcuma aff. amada are used for detoxification and for their anti-inflammatory effects. However, neither species has been investigated for detoxification activity. Because the seeds and leaves of Crotalaria spectabilis have been reported to contain a pyrrolizidine alkaloid, which causes hepatotoxicity in humans and animals ${ }^{8}$, users of this species as a form of 'Rang Chuet' should be cautious.

Commercial products of 'Rang Chuet' in tea, capsule, and powder forms in herbal markets are claimed to have antidote, antipyretic, and anti-inflammatory effects. However, confusion has arisen because of the similarity in the vernacular names of the plants. 
From our market survey, the scientific name of the plant identified in those products was inconsistent with the labelled illustration. Therefore, two tasks must be accomplished to address these problems and ensure the safety and efficacy of the herbal drug 'Rang Chuet': (1) the biological potencies of the herbal drugs must be clarified based on their medicinal uses; and (2) the herbal drugs derived from different plants must be distinguished from each other.

The antioxidant activities of $T$. laurifolia were previously demonstrated by Oonsivilai et $\mathrm{al}^{9}$, and some flavonoids and phenolic compounds were suggested to be the active components of this species. However, antioxidant activity and detoxification have never been evaluated in Crotalaria spectabilis and Curcuma aff. amada. In this study, two different antioxidant assays, the 2,2-diphenyl-1-picrylhydrazyl (DPPH) radical scavenging activity and the ferric reducing antioxidant power (FRAP) assay, were conducted, and the results were coupled with the determination of the total phenolic contents to verify the antioxidant activities of these species.

For a more reliable and comprehensive system of botanical characterization, conventional identification methods should be properly integrated with molecular techniques ${ }^{10}$. Conventional identification, including macroscopic and microscopic evaluation and chemical profiling of the botanical materials is generally suggested by regulatory guidelines and pharmacopoeias. Currently, TLC profiling, which provides the first characteristic fingerprints of herbs, is still used in various pharmacopoeias for the analysis of herbal medicines ${ }^{11-14}$.

DNA techniques have been adapted for the authentication of herbs in recent years ${ }^{15}$. PCR-RFLP is one of the most popular DNA-based techniques for species identification in biology, medicine, and food science ${ }^{16}$. The method was successfully used to differentiate Alisma orientale from Alisma species ${ }^{17}$ and Bulbus fritillariae from its adulterants ${ }^{18}$ and to identify species in anchovy pastes on the market ${ }^{19}$.

The aim of the present study was to identify the antioxidant properties of the three 'Rang Chuet' species, including T. laurifolia, Crotalaria spectabilis, and Curcuma aff. amada. TLC chemical profiling and PCR-RFLP fingerprinting based on the matK gene were also used to identify the three species.

\section{MATERIALS AND METHODS}

\section{Chemicals and equipment}

The 2,2-diphenyl-1-picrylhydrazyl (DPPH) radical, 2,4,6-tris(2-pyridyl)-s-triazine (TPTZ), 2,5,7,8-tetra- methylchroman-2-carboxylic acid (Trolox), FolinCiocalteu reagent, ascorbic acid, and catechin were purchased from Sigma-Aldrich (Missouri, USA). A UV-160A spectrophotometer (Shimadzu, Japan) was used for spectrophotometric measurements. A Victor3 microplate reader (Perkin Elmer, USA) was used for the DPPH assay.

The DNeasy Plant Mini Kit and Dream Taq polymerase were obtained from Qiagen (Hilden, Germany) and Fermentas (Ontario, Canada), respectively. The restriction enzymes DdeI and HaeIII were purchased from New England Biolabs (Massachusetts, USA). PCR was performed in a C1000 thermal cycler (Bio-Rad, USA) and documented with a Gel Doc XR ${ }^{+}$ system (Bio-Rad, USA).

\section{Plant materials and preparation of plant extracts}

Details of the plants recognized as 'Rang Chuet' are shown in Table 1. Dried leaves of T. laurifolia and Crotalaria spectabilis and dried rhizomes of Curcuma aff. amada were collected from various locations and identified by Associate Professor Chaiyo Chaichantipyuth, Ph.D. at the Department of Pharmacognosy and Pharmaceutical Botany, Faculty of Pharmaceutical Sciences, Chulalongkorn University, Thailand. Voucher specimens of the plant materials were preserved in the Museum of Natural Medicines at the Faculty of Pharmaceutical Sciences, Chulalongkorn University.

Samples of T. laurifolia, Crotalaria spectabilis, and Curcuma aff. amada, with voucher no. SS0809101, SS-0909401, and SS-0809601, were used for extraction and analysis. To prepare extracts, plants were ground into a powder with an electric blender. Then, the fine powder $(20 \mathrm{~g})$ of each species was independently extracted with $200 \mathrm{ml}$ of either ethanol or distilled water. The ethanolic extracts were macerated at room temperature for $72 \mathrm{~h}$, whereas the aqueous extracts were heated and stirred on a hotplate for $30 \mathrm{~min}^{20}$. Subsequently, each extract was filtered with Whatman No. 1 filter paper. The filtrates obtained from the ethanolic and aqueous extracts were individually dried by evaporation at $50{ }^{\circ} \mathrm{C}$ or lyophilization, respectively.

\section{DPPH radical scavenging activity}

Radical scavenging activity was evaluated with a standard spectrophotometric assay with the DPPH radical in a 96-well microplate with modifications ${ }^{21}$. A 20 $\mu \mathrm{l}$ aliquot of the sample extract and $180 \mu \mathrm{l}$ of a $0.1 \mathrm{mM}$ methanolic DPPH solution were added to each well. The plate was covered with aluminium foil and incubated at room temperature for $30 \mathrm{~min}$. The 
Table 1 Details of the plant samples used in this study.

\begin{tabular}{|c|c|c|c|c|c|}
\hline Plant & Code & Family & Location (Province) & Voucher specimen & Accession number \\
\hline \multirow[t]{8}{*}{ T. laurifolia Lindl. } & \multirow[t]{8}{*}{$\mathrm{TL}$} & \multirow[t]{8}{*}{ Acanthaceae } & Bangkok & SS-0809101 & \multirow[t]{8}{*}{ AB649970 } \\
\hline & & & Nakhon Si Thammarat & SS-1009102 & \\
\hline & & & Buri Ram & SS-1009103 & \\
\hline & & & Prachin Buri & SS-1009104 & \\
\hline & & & Nakhon Pathom & SS-0510105 & \\
\hline & & & Nonthaburi & SS-0510106 & \\
\hline & & & Uttaradit & SS-1010107 & \\
\hline & & & Chiang Mai & SS-1110108 & \\
\hline \multirow[t]{3}{*}{ Curcuma aff. amada (Roxb.) } & \multirow[t]{3}{*}{ CUR } & \multirow[t]{3}{*}{ Zingiberaceae } & Chachoengsao & SS-0909401 & \multirow[t]{3}{*}{ AB649974 } \\
\hline & & & Ratchaburi & SS-0710402 & \\
\hline & & & Prachin Buri & SS-0710403 & \\
\hline \multirow[t]{2}{*}{ Crotalaria spectabilis Roth } & \multirow[t]{2}{*}{$\mathrm{CS}$} & \multirow[t]{2}{*}{ Fabaceae } & Nakhon Pathom & SS-0809601 & \multirow[t]{2}{*}{ AB649973 } \\
\hline & & & Bangkok & SS-1209602 & \\
\hline
\end{tabular}

absorbance was measured at $510 \mathrm{~nm}$ against a solvent blank to estimate the radical scavenging capacity of each antioxidant sample. The free radical scavenging activities of the plant extracts were compared with ascorbic acid, which served as a positive control ${ }^{22}$. The scavenging capacity was reported as the effective concentration at which $50 \%$ of the DPPH radicals were scavenged $\left(\mathrm{EC}_{50}\right.$ value).

\section{Ferric-reducing antioxidant power}

FRAP was measured according to the method developed by Benzie and Strain ${ }^{23}$. The FRAP working solution was prepared from $300 \mathrm{mM}$ acetate buffer, $\mathrm{pH} 3.6$ (3.1 g CH $\mathrm{CH}_{3} \mathrm{COONa} \cdot 3 \mathrm{H}_{2} \mathrm{O}$ and $16 \mathrm{ml}$ of $\mathrm{CH}_{3} \mathrm{COOH}$ adjusted to $1000 \mathrm{ml}$ with distilled water), $10 \mathrm{mM}$ TPTZ solution in $40 \mathrm{mM} \mathrm{HCl}$, and $20 \mathrm{mM}$ $\mathrm{FeCl}_{3}$ solution in a ratio of 10:1:1. The plant extract solution $(2 \mathrm{mg} / \mathrm{ml}, 20 \mu \mathrm{l})$ was allowed to react with $600 \mu \mathrm{l}$ of the FRAP working solution for $4 \mathrm{~min}$ at room temperature. The absorbance of the coloured product was then measured at $595 \mathrm{~nm}$. A Trolox standard solution was used to prepare the calibration curves. The values are expressed as $\mu \mathrm{M}$ Trolox equivalents (TE) per g dry weight.

\section{Total phenolic content}

The total phenolic content (TPC) was analysed according to the method developed by Amarowicz et $\mathrm{al}^{24}$, with modifications. Five concentrations of catechin were prepared for use as standards. Each reaction mixture contained $20 \mu \mathrm{l}$ of a standard catechin solution or $20 \mu \mathrm{l}$ of a sample solution $(2 \mathrm{mg} / \mathrm{ml})$, $770 \mu \mathrm{l}$ distilled water, and $60 \mu \mathrm{l}$ Folin-Ciocalteu reagent. After $1 \mathrm{~min}$ but before $8 \mathrm{~min}, 200 \mu \mathrm{l}$ of a saturated $\mathrm{Na}_{2} \mathrm{CO}_{3}$ solution was added. The reagent blank was prepared by replacing the sample solution with $20 \mu \mathrm{l}$ of the extracted solvent. After $2 \mathrm{~h}$ of reaction at ambient temperature, the absorbance of each reaction mixture was measured at $760 \mathrm{~nm}$. The value of the total phenolic contents was expressed as catechin equivalents (CE) per $g$ of dry weight. The values were determined from the linear equation based on the calibration curve of catechin.

\section{TLC characterization}

The plant extracts $(0.2 \mathrm{mg})$ were applied to a silica gel TLC plate as 8-mm-wide bands. For the ethanolic extract, the plates were developed in chloroformmethanol-formic acid (7:3:0.5). For the aqueous extract, the bands were eluted with a solvent solution composed of ethyl acetate-formic acid-acetic acidwater (10:0.8:0.8:2.8). The chromatograms were evaluated under UV light at 254 and $365 \mathrm{~nm}$ to detect the target compounds. To detect flavonoid compounds, the TLC plate was also sprayed with a $1 \% \mathrm{AlCl}_{3}$ solution and monitored under UV light at $365 \mathrm{~nm}^{25}$. In the aqueous extracts, phenolic compounds were detected with $20 \% \mathrm{Na}_{2} \mathrm{CO}_{3}$ solution and Folin-Ciocalteu reagent ${ }^{26}$ because no flavonoid compounds were detected in these extracts. The TLC bioautography assay of radical scavenging activity with the DPPH radical was also employed. The chromatogram was sprayed with a $0.5 \mathrm{mM}$ methanolic solution of DPPH to detect antioxidant compounds.

\section{DNA isolation and the PCR-RFLP method}

A total of $100 \mathrm{mg}$ of the plant samples was frozen and ground to obtain a fine powder. The total DNA was isolated with the DNeasy Plant Mini Kit (Qiagen, Germany) according to the manufacturer's protocol.

A pair of amplification primers, the matK-465F primer $\left(5^{\prime}\right.$-ACT AAT ACC CTA TCC TGT CCA T-3') 
and the matK-1483R primer (5'-CCA AAT ACC AAA TCC GWC CTC TA- $3^{\prime}$ ), was designed to amplify an approximately $1 \mathrm{~kb}$ fragment of the $m a t \mathrm{~K}$ gene from T. laurifolia, Curcuma aff. amada, and Crotalaria spectabilis. The $50 \mu \mathrm{l}$ reaction mixture was composed of $1 \mathrm{X}$ amplification buffer, $2.5 \mathrm{mM} \mathrm{MgCl} 2$, dNTPs ( $0.2 \mathrm{mM}$ each), the two primers ( $0.5 \mu \mathrm{M}$ each), $1.25 \mathrm{U}$ Dream Taq Polymerase, and 20 ng of total DNA as the template. The PCR amplifications were performed with a DNA thermal cycler with the cycling conditions of a hot start at $95^{\circ} \mathrm{C}$ for $2 \mathrm{~min} ; 40$ cycles of $95^{\circ} \mathrm{C}$ for $30 \mathrm{~s}, 56^{\circ} \mathrm{C}$ for $45 \mathrm{~s}$ and $72^{\circ} \mathrm{C}$ for $2 \mathrm{~min}$; and a final extension at $72^{\circ} \mathrm{C}$ for $5 \mathrm{~min}$. A 5 - $\mu \mathrm{l}$ sample of the resulting PCR product was subjected to electrophoresis on a $1.0 \%$ agarose gel, and the remaining sample was sequenced with the primers listed above. The determined nucleotide sequences were deposited in the DDBJ/EMBL/GenBank nucleotide sequence database (Table 1).

RFLP patterns were analysed with the CLC Sequence Viewer software ${ }^{27}$. According to the preliminary computerized analysis, DdeI and HaeIII were selected as suitable candidate enzymes to identify the three species. A $10-\mu l$ aliquot of the PCR product was digested with DdeI and HaeIII for 5 h at $37^{\circ} \mathrm{C}$ in a total volume of $20 \mu \mathrm{l}$ according to the manufacturer's protocol. The restriction products were examined by gel electrophoresis on $1.5 \%$ agarose gels and visualized by ethidium bromide staining with a gel documentation system.

\section{RESULTS AND DISCUSSION}

Confusing herb nomenclature is clearly a significant problem in the herbal markets of many countries ${ }^{28,29}$. When one herb is used in place of another, the curative effects are not as expected. Similarly, the confusion caused from using the same common name 'Rang Chuet' for the three different herbs, T. laurifolia, Crotalaria spectabilis, and Curcuma aff. amada, in herbal drugs and herbal preparations is currently a problem in Thai herbal markets. Each of these three species is claimed to have detoxifying effects; however, there is insufficient information to prove whether they are, in fact, equally effective as herbal drugs. The identification of the plant materials is also necessary to assure the safe and effective use of the 'Rang Chuet' herbal drugs.

\section{Antioxidant effects and phenolic content of plant extracts}

Various detoxifying effects related with antioxidant properties of the medicinal plants have been reported. For instance, free radical scavenging activity was

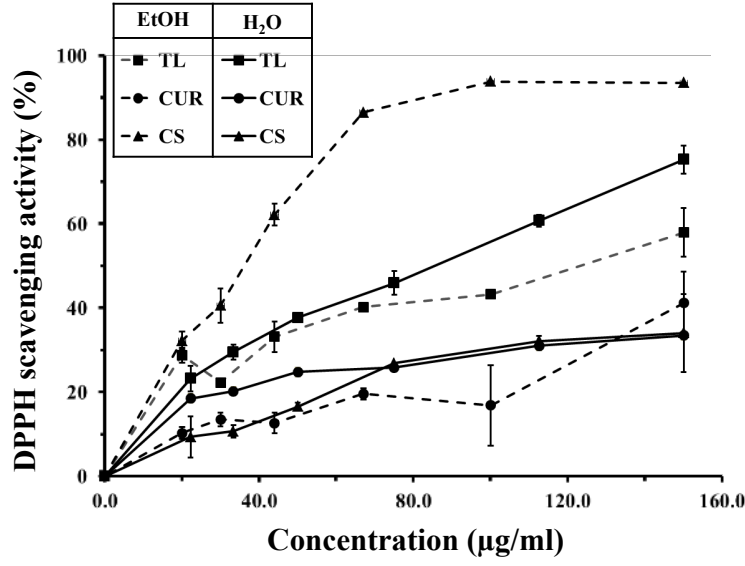

Fig. 1 DPPH radical scavenging activities of the ethanolic and aqueous extracts of T. laurifolia, Crotalaria spectabilis, and Curcuma aff. amada. The values are expressed as the mean of three replicates \pm SD.

linked with gastroprotective properties from the butanolic fraction of Argyreia speciosa (L.f.) ${ }^{30}$. The hepatoprotective effects of Nelumbo nucifera Gaertn. seeds extract against carbon tetrachloride and aflatoxin B1 might results from its potent antioxidative properties $^{31}$. Since several detoxifying effects of T. laurifolia extracts related with antioxidant properties including hepatoprotective properties ${ }^{32}$, neural protection against lead poisoning ${ }^{5}$, and antimutagen activity ${ }^{33}$ have been recently reported, antioxidant assays of other 'Rang Chuet' plants were performed in this study.

Two assays, the DPPH radical scavenging assay and the FRAP assay, which are based on different reaction mechanisms, were employed to evaluate the antioxidant capacity of $T$. laurifolia, Crotalaria spectabilis, and Curcuma aff. amada. In the DPPH analysis, the scavenging activities of the three species against the DPPH radical depended on concentration (Fig. 1). As shown in Table 2, the scavenging capacity of the ethanolic extract of Crotalaria spectabilis $\left(\mathrm{EC}_{50}\right.$ value $=26.6 \pm 1.4 \mu \mathrm{g} / \mathrm{ml}$ ) was notably higher than that of T. laurifolia $\left(\mathrm{EC}_{50}\right.$ value $\left.=120 \pm 13 \mu \mathrm{g} / \mathrm{ml}\right)$ or Curcuma aff. amada $\left(\mathrm{EC}_{50}\right.$ value $\left.>150 \mu \mathrm{g} / \mathrm{ml}\right)$. The ability of the ethanolic extracts to reduce $\mathrm{Fe}^{3+}$ to $\mathrm{Fe}^{2+}$ was also highest for Crotalaria spectabilis $(204 \pm 38 \mu \mathrm{M} \mathrm{TE} / \mathrm{g})$. This is the first report of the radical scavenging activity and reducing power of an ethanolic extract of Crotalaria spectabilis, which represents a good source of a potential natural antioxidant. Of the aqueous extracts, T. laurifolia possessed both the highest DPPH scavenging activity $\left(\mathrm{EC}_{50}\right.$ value $=86 \pm 4 \mu \mathrm{g} / \mathrm{ml}$ ) and the highest ferric-reducing 
Table 2 Antioxidant properties and total phenolic contents of the ethanolic and aqueous extracts of T. laurifolia, Curcuma aff. amada, and Crotalaria spectabilis. The values are expressed as the mean of three replicates $\pm \mathrm{SD}$.

\begin{tabular}{|c|c|c|c|c|}
\hline Plant & Extract & $\mathrm{EC}_{50}(\mu \mathrm{g} / \mathrm{ml})$ of DPPH test & FRAP ( $\mu$ M TE/g dry weight) & TPC (mg CE/g dry weight) \\
\hline \multirow[t]{2}{*}{ T. laurifolia } & Ethanol & $120 \pm 13$ & $155 \pm 8^{\mathrm{a}}$ & $26.5 \pm 0.1^{\mathrm{a}}$ \\
\hline & Aqueous & $86 \pm 4$ & $148 \pm 8^{\mathrm{x}}$ & $35.8 \pm 0.1^{\mathrm{x}}$ \\
\hline \multirow[t]{2}{*}{ Curcuma aff. amada } & Ethanol & n.d. ${ }^{*}$ & $66 \pm 14^{\mathrm{b}}$ & $17.9 \pm 0.1^{\mathrm{b}}$ \\
\hline & Aqueous & n.d. ${ }^{*}$ & $35 \pm 4^{\mathrm{y}}$ & $12.3 \pm 0.1^{\mathrm{y}}$ \\
\hline \multirow[t]{2}{*}{ Crotalaria spectabilis } & Ethanol & $26.6 \pm 1.4$ & $204 \pm 38^{\mathrm{a}}$ & $40.8 \pm 1.1^{\mathrm{c}}$ \\
\hline & Aqueous & n.d. & $67 \pm 12^{\mathrm{z}}$ & $14.9 \pm 0.0^{\mathrm{z}}$ \\
\hline Ascorbic acid & - & $12.7 \pm 1.2$ & - & - \\
\hline
\end{tabular}

\footnotetext{
* Not detectable because the maximum concentration used in this experiment was not sufficient to scavenge $50 \%$ of the DPPH radicals. The significance levels were individually calculated for each ethanolic or aqueous extract. Different letters ( $\mathrm{a}, \mathrm{b}, \mathrm{c}$ or $\mathrm{x}, \mathrm{y}, \mathrm{z})$ within the same column indicate a significant difference at $p<0.05$ by Tukey's test.
}

power $(148 \pm 8 \mu \mathrm{M} \mathrm{TE} / \mathrm{g})$. In addition, the aqueous extract of T. laurifolia exhibited greater antioxidant properties than its ethanolic counterpart, in agreement with an earlier report ${ }^{9}$. Those results support the traditional application of T. laurifolia as a herbal tea in a decoction with boiling water ${ }^{34}$.

Phenolic compounds have been recognized as natural antioxidants in various plants ${ }^{35}$, including T. laurifolia ${ }^{9}$. In this study, the highest total phenolic content was found in the ethanolic extract of Crotalaria spectabilis $(40.8 \pm 1.1 \mathrm{mg} / \mathrm{g})$, which possessed the highest antioxidant activity, followed by the aqueous and ethanolic portions of T. laurifolia, which included $35.8 \pm 0.1$ and $26.5 \pm 0.1 \mathrm{mg} \mathrm{CE} / \mathrm{g}$, respectively. The antioxidant activities of the extracts appear to be influenced by the total phenolic levels. Several studies have revealed that the phenolic contents of these plants are associated with their antioxidant activities, most likely due to the redox properties of these compounds, which allow them to act as reducing agents, hydrogen donors, and singlet oxygen quenchers ${ }^{36}$. According to the results, the antioxidant potencies of $T$. laurifolia, Crotalaria spectabilis, and Curcuma aff. amada differ, implying that the substituted use of medicinal plants known as 'Rang Chuet' requires caution. However, more specific pharmacological activities related to traditional indications should be further investigated to better verify the biological functions and medicinal uses of these plants.

\section{Chemical characterization by TLC}

The characteristic chemical pattern indicated by TLC profiling is useful for the primary identification of plant materials. The TLC mobile phases for the crude extracts of T. laurifolia, Crotalaria spectabilis, and Curcuma aff. amada were optimized empirically. The chemical profiles of the ethanolic extracts of the three species are shown in Fig. 2a and 2b. Flavonoids, which turn yellow under UV light at $365 \mathrm{~nm}$ after being sprayed with an $\mathrm{AlCl}_{3}$ solution, were found in the ethanolic extracts of T. laurifolia and Crotalaria spectabilis at $\mathrm{R}_{\mathrm{f}} 0.05$, and 0.17 , respectively (Fig. 2a). However, no flavonoid compound was detected in the ethanolic extract of Curcuma aff. amada. When the DPPH solution was applied to the ethanolic extracts of T. laurifolia and Crotalaria spectabilis, numerous bands were detected on the TLC plate (Fig. 2b). These results indicate that the ethanolic extracts of $T$. laurifolia and Crotalaria spectabilis are rich in natural antioxidant compounds detected in the free radical scavenging assay. These results also agree well with the spectrophotometric analysis of antioxidant activity, which indicated the high antioxidant capacities of the ethanolic extracts of Crotalaria spectabilis and T. laurifolia.

Because flavonoid compounds were not detected in the aqueous extracts of T. laurifolia, Crotalaria spectabilis, and Curcuma aff. amada, the components of the aqueous extracts were characterized based on the phenolic compounds. The bands that were visible on the developed TLC plate after the plate was sprayed with $20 \% \mathrm{Na}_{2} \mathrm{CO}_{3}$ and the Folin-Ciocalteu reagent were identified as phenolic compounds. As shown in Fig. 2c, the compounds were observed in the aqueous extracts of T. laurifolia and Crotalaria spectabilis. The characteristic bands of phenolic compounds were observed at $\mathrm{R}_{\mathrm{f}} 0.62$ and 0.95 for $T$. laurifolia, whereas those of Crotalaria spectabilis were detected at different positions $\left(\mathrm{R}_{\mathrm{f}} 0.05\right.$ and 0.20$)$. In contrast, phenolic compounds were not found in the extract of Curcuma aff. amada. The DPPH solution was also applied to the TLC plates on which the aqueous extracts were separated to detect radical scavengers. The DPPH-scavenger-active bands of T. laurifolia and Crotalaria spectabilis coincided with the phenolic compounds detected on the TLC plates (Fig. 2d). 
(a)

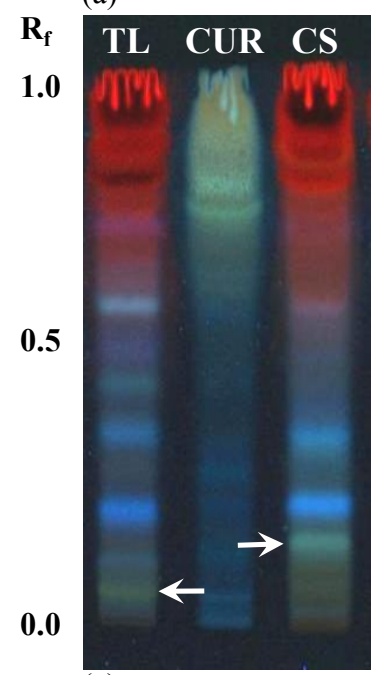

(c)

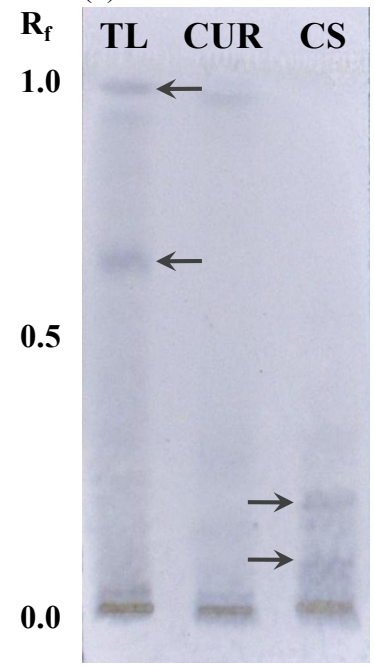

(b)

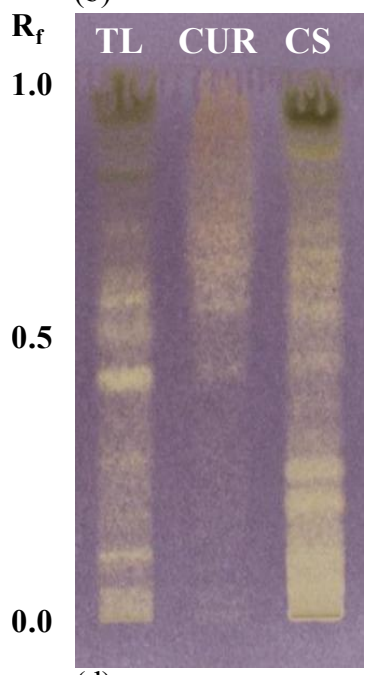

(d)

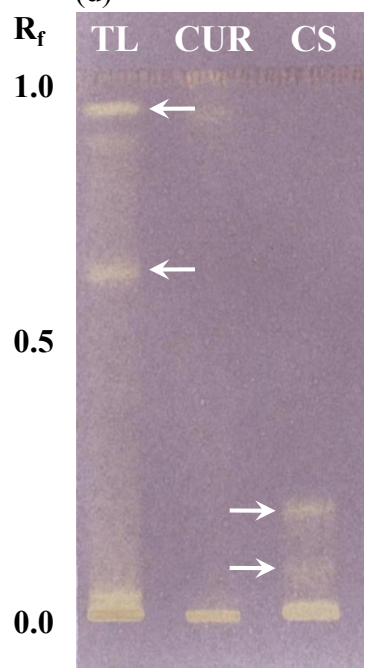

Fig. 2 TLC chromatograms of the ethanolic and aqueous extracts of T. laurifolia, Curcuma aff. amada, and Crotalaria spectabilis. The plates of the ethanolic extracts were developed with chloroform-methanol-formic acid (7:3:0.5) and then viewed (a) under UV light at $365 \mathrm{~nm}$ after being sprayed with $1 \% \mathrm{AlCl}_{3}$ or (b) under visible light after being sprayed with a $0.5-\mathrm{mM}$ DPPH solution. The plates of the aqueous extracts were developed with ethyl acetate-formic acid-acetic acid-water (10:0.8:0.8:2.8) and then viewed (c) under visible light after being sprayed with the Folin-Ciocalteu reagent or (d) under visible light after being sprayed with a $0.5-\mathrm{mM}$ DPPH solution.

These results suggest that these phenolic compounds may contribute to the antioxidant properties of the plants. On the basis of the chemical characteristics of these medicinal plants, TLC analysis should be one of methods used to rapidly characterize 'Rang

Chuet' herbal drugs. The three medicinal plants, T. laurifolia, Crotalaria spectabilis, and Curcuma aff. amada, can be distinguished based on their flavonoid and phenolic constituents and their DPPH-scavenging profiles, which exhibited characteristic marks upon the development of the TLC plates of the ethanolic and aqueous extracts.

\section{Development of the PCR-RFLP method for species differentiation}

Although there are several identification methods available, no single method is sufficient to identify herbal drugs. Applying various methods in concert is necessary to conclusively confirm an identification or authentication ${ }^{28}$. A DNA-based technique is a supplementary method for this task. Herein, a convenient PCR-RFLP method based on the matK gene that would enable rapid and accurate identification was developed to differentiate between T. laurifolia, Crotalaria spectabilis, and Curcuma aff. amada. As indicated in many previous studies, the sequence of the chloroplast mat $\mathrm{K}$ gene provides useful information to assist in the taxonomic classification and identification of the botanical origin of herbal drugs ${ }^{37,38}$. The primer set matK-465F and matK-1483R was designed to amplify a short fragment of the matK gene because the DNA extracted from the crude drug sample was generally degraded, thus making the amplification of a long PCR fragment difficult ${ }^{39}$. The PCR product of each species exhibited a single band in the electrophoresis profile, corresponding to a fragment size of approximately $1 \mathrm{~kb}$.

Based on the alignment of the products, polymorphic nucleotides were observed at various sites of the mat $\mathrm{K}$ products of the three species, permitting the differentiation of T. laurifolia, Crotalaria spectabilis, and Curcuma aff. amada with the restriction enzymes DdeI and HaeIII, which can recognize and cleave the sequences $\mathrm{C}^{\wedge} \mathrm{TXAG}$ and $\mathrm{GG}^{\wedge} \mathrm{CC}$, respectively. The locations of the restriction sites recognized by DdeI and HaeIII differed among the three sequences of T. laurifolia, Crotalaria spectabilis, and Curcuma aff. amada (Fig. 3), yielding different fragment sizes that can be observed by gel electrophoresis (Fig. 4). DdeI cleaved the 1046-bp fragment of T. laurifolia that was amplified by matK-465F and matK-1483R into 934- and 112-bp fragments. The Curcuma aff. amada sequence includes one restriction site for $D d e \mathrm{I}$ at position 687, and fragments of $627 \mathrm{bp}$ and 407 bp were observed after digestion. For Crotalaria spectabilis, the 1037-bp PCR product was cleaved into 230-bp and 807-bp fragments by DdeI. There is one restriction site specific to HaeIII in the sequence 


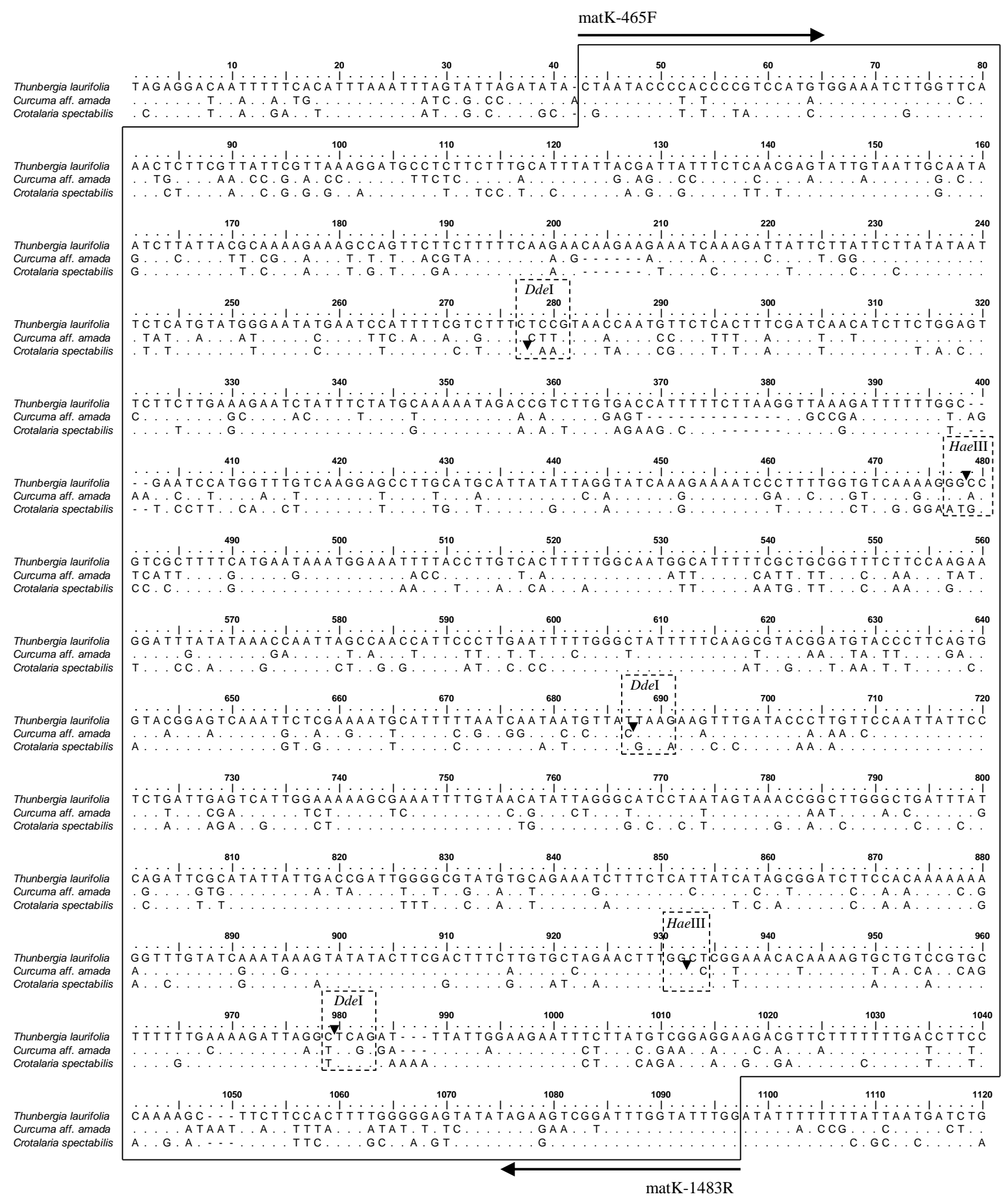

Fig. 3 Sequence alignment of the partial matK gene from T. laurifolia, Crotalaria spectabilis, and Curcuma aff. amada. The first position of the alignment corresponds to nucleotide position 404, 425, and 407 of the matK genes of T. laurifolia, Curcuma aff. amada, and Crotalaria spectabilis, respectively. The arrows indicate the locations of the primers matK- $465 \mathrm{~F}$ and matK-1483R. Dots denote nucleotides identical to those of the T. laurifolia sequence. The gaps that were introduced to maintain alignment are indicated by dots. The restriction sites for DdeI (C^TXAG) and HaeIII (GG^CC) in the three sequences are indicated by a dashed box. 
(a)

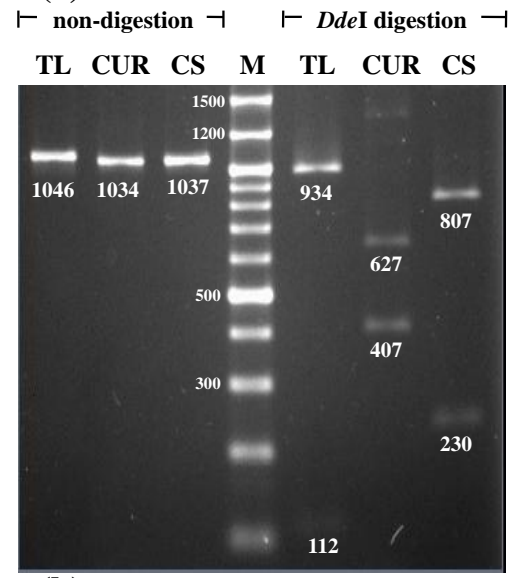

(b)
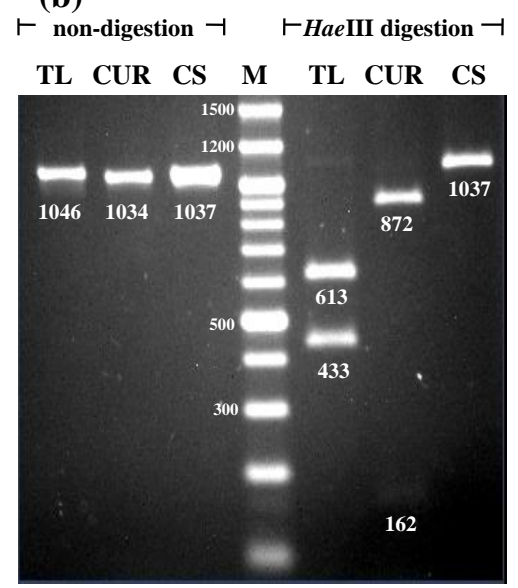

Fig. 4 PCR-RFLP patterns of the matK products of T. laurifolia, Crotalaria spectabilis, and Curcuma aff. amada digested with (a) DdeI and (b) HaeIII. Gel electrophoresis was performed on a $1.5 \%$ agarose gel, which was stained with ethidium bromide. The DNA markers (VC 100 bp plus, Vivantis, USA) are indicated as bp units in lane $\mathrm{M}$.

of T. laurifolia, resulting in the cleavage of the PCR product into two fragments of $433 \mathrm{bp}$ and $613 \mathrm{bp}$ in length. HaeIII can digest the 1034-bp matK fragment of Curcuma aff. amada into 872-bp and 162-bp fragments, whereas there is no HaeIII restriction site in the Crotalaria spectabilis sequence. The different fragment sizes observed via gel electrophoresis after digestion with DdeI and HaeIII represent a good diagnostic tool to differentiate between $T$. laurifolia, Crotalaria spectabilis, and Curcuma aff. amada.

\section{CONCLUSIONS}

Confusion regarding 'Rang Chuet' herbal drugs has arisen in Thai herbal markets because of similar nomenclature. T. laurifolia, Crotalaria spectabilis, and Curcuma aff. amada are all known by the same local name. However, these plants exhibit different antioxidant effects, as demonstrated by DPPH and FRAP assays. High antioxidant capacities were observed in T. laurifolia and Crotalaria spectabilis that may be influenced by the presence of phenolic components in the extracts. Because herbal drugs are often processed into powders during preparation, species identification based on histological characteristics may not be applicable. Chemical profiling and DNA analysis were used in tandem to identify the plant materials. The TLC results indicated that these different species can be identified based on the flavonoid and phenolic constituents of the ethanolic and aqueous extracts, respectively. Development of the TLC plates with the DPPH radical permitted the detection of radicalscavenging compounds in T. laurifolia and Crotalaria spectabilis. The PCR-RFLP technique has potential for identifying species present in 'Rang Chuet' herbal drugs. After digestion with specific restriction enzymes, T. laurifolia, Crotalaria spectabilis, and Curcuma aff. amada were easily distinguished based on the different sizes of the digested fragments. The use of both TLC and PCR-RFLP analyses permits the identification of species via the comparison of unknown samples with standard patterns.

Acknowledgements: P.S. was a recipient of C.U. Graduate School Thesis Grant. This study was financially supported by the Higher Education Research Promotion and National Research University Project of Thailand, Office of the Higher Education Commission (HR1166I). We also thank Chulalongkorn University Centenary Academic Development Project for providing facilities.

\section{REFERENCES}

1. Ussanawarong S, Thesiri T, Mahakunakorn P, Parasupattana S (2000) Effect of Thunbergia laurifolia Linn. on detoxification of paraquat. KKU Res $J \mathbf{5}, 11-7$.

2. Ussanawarong S, Thesiri T (2001) Effect of Thunbergia laurifolia Linn. on detoxification of parathion in rat. KKU Res J 6, 3-13.

3. Pramyothin P, Chirdchupunsare H, Rungsipipat A, Chaichantipyuth C (2005) Hepatoprotective activity of Thunbergia laurifolia Linn extract in rats treated with ethanol: In vitro and in vivo studies. J Ethnopharmacol 102, 408-11.

4. Thongsaard W, Marsden CA, Morris P, Prior M, Shah YB (2005) Effect of Thunbergia laurifolia, a Thai natural product used to treat drug addiction, on cerebral activity detected by functional magnetic resonance imaging in the rat. Psychopharmacology 180, 752-60.

5. Tangpong J, Satarug S (2010) Alleviation of lead poisoning in the brain with aqueous leaf extract of the Thunbergia laurifolia (Linn.). Toxicol Lett 198, 83-8. 
6. Pilapoch S, Jiraungkoorskul W, Tansatit T, Preyavichyapugdee N, Jaikua W, Kosai P (2011) Protective efficiency of Thunbergia laurifolia leaf extract against lead (II) nitrate-induced toxicity in Oreochromis niloticus. $J$ Med Plant Res 5, 719-28.

7. Chan EWC, Eng SY, Tan YP, Wong ZC (2011) Phytochemistry and pharmacological properties of Thunbergia laurifolia: a review. Phcog J 3, 1-6.

8. Schultze AE, Roth RA (1998) Chronic pulmonary hypertension-the monocrotaline model and involvement of the hemostatic system. J Toxicol Environ Health B Crit Rev 1, 271-346.

9. Oonsivilai R, Ferruzzi MG, Ningsanond S (2008) Antioxidant activity and cytotoxicity of Rang Chuet (Thunbergia laurifolia Lindl.) extracts. Asian J Food Agro Ind 1, 116-28.

10. Joshi K, Chavan P, Warude D, Patwardhan B (2004) Molecular markers in herbal drug technology. Curr Sci 87, 159-65.

11. Liang Y-Z, Xie P, Chan K (2004) Quality control of herbal medicines. J Chrom B 812, 53-70.

12. Vermaak I, Hamman JH, Viljoen AM (2010) High performance thin layer chromatography as a method to authenticate Hoodia gordonii raw material and products. J S Afr Bot 76, 119-24.

13. Vogel H, González M, Faini F, Razmilic I, Rodríguez J, San Martín J, Urbina F (2005) Antioxidant properties and TLC characterization of four Chilean Haplopappus-species known as bailahuen. J Ethnopharmacol 97, 97-100.

14. West BJ, Deng S (2010) Thin layer chromatography methods for rapid identity testing of Morinda citrifolia L. (Noni) fruit and leaf. Adv J Food Sci Tech 2, 298-302.

15. Zhang YB, Shaw PC, Sze CW, Wang ZT, Tong Y (2007) Molecular authentication of Chinese herbal materials. J Food Drug Anal 15, 1-9.

16. Lin WF, Hwang DF (2007) Application of PCR-RFLP analysis on species identification of canned tuna. Food Contr 18, 1050-7.

17. Li X, Ding X, Chu B, Ding G, Gu S, Qian L, Wang Y, Zhou Q (2006) Molecular authentication of Alisma orientale by PCR-RFLP and ARMS. Planta Med 73, 67-70.

18. Wang CZ, Li P, Ding JY, Peng X, Yuan CS (2007) Simultaneous identification of Bulbus Fritillariae cirrhosae using PCR-RFLP analysis. Phytomedicine 14, 628-32.

19. Rea S, Storani G, Mascaro N, Stocchi R, Loschi AR (2009) Species identification in anchovy pastes from the market by PCR-RFLP technique. Food Contr 20, 515-20.

20. Thongsaard W, Marsden CA (2002) A herbal medicine used in the treatment of addiction mimics the action of amphetamine on in vitro rat striatal dopamine release. Neurosci Lett 329, 129-32.

21. Kintzios S, Papageorgiou K, Yiakoumettis I, Baricevic
D, Kusar A (2010) Evaluation of the antioxidants activities of four Slovene medicinal plant species by traditional and novel biosensory assays. J Pharmaceut Biomed Anal 53, 773-6.

22. Arabshahi-Delouee S, Urooj A (2007) Antioxidant properties of various solvent extracts of mulberry (Morus indica L.) leaves. Food Chem 102, 1233-40.

23. Benzie IFF, Strain JJ (1996) The ferric reducing ability of plasma (FRAP) as a measure of "antioxidant power": The FRAP assay. Anal Biochem 239, 70-6.

24. Amarowicz R, Estrella I, Hernández T, Robredo S, Troszyńska A, Kosińska A, Pegg RB (2010) Free radical-scavenging capacity, antioxidant activity, and phenolic composition of green lentil (Lens culinaris). Food Chem 121, 705-11.

25. Gage TB, Douglass CD, Wender SH (1951) Identification of flavonoid compounds by filter paper chromatography. Anal Chem 23, 1583-5.

26. Keith RW, Le Tourneau D, Muhlum D (1958) Quantitative paper-chromatographic determination of phenols. J Chrom A 1, 534-6.

27. Joo S, Lee S-R, Park S (2010) Monitoring of phytoplankton community structure using terminal restriction fragment length polymorphism (T-RFLP). $J M i$ crobiol Meth 81, 61-8.

28. Zhao Z, Hu Y, Liang Z, Yuen JPS, Jiang Z, Leung KSY (2006) Authentication is fundamental for standardization of Chinese medicines. Planta Med 72, 865-74.

29. Zhao Z, Yuen JPS, Wu J, Yu T, Huang W (2006) A systematic study on confused species of Chinese Materia Medica in the Hong Kong Market. Ann Acad Med Singapore 35, 764-9.

30. Jaiswal SK, Rao CV, Sharma B, Mishra P, Das S, Dubey MK (2011) Gastroprotective effect of standardized leaf extract from Argyreia speciosa on experimental gastric ulcers in rats. J Ethnopharmacol 137, 341-4.

31. Sohn D-H, Kim Y-C, Oh S-H, Park E-J, Li X, Lee B$\mathrm{H}$ (2003) Hepatoprotective and free radical scavenging effects of Nelumbo nucifera. Phytomedicine 10, 165-9.

32. Wonkchalee O, Boonmars T, Aromdee C, Laummaunwai P, Khunkitti W, Vaeteewoottacharn K, Sriraj P, Aukkanimart R, et al (2012) Anti-inflammatory, antioxidant and hepatoprotective effects of Thunbergia laurifolia Linn. on experimental opisthorchiasis. Parasitol Res 111, 353-9.

33. Oonsivilai R, Cheng C, Bomser J, Ferruzi MG, Ningsanond S (2007) Phytochemical profiling and phase II enzyme-inducing properties of Thunbergia laurifolia Lindl. (RC) extracts. J Ethnopharmacol 114, 300-6.

34. Wutythamawech W (1997) Encyclopedia of Thai Herbs. OS Printing House, Bangkok, p 390.

35. Krishnaiah D, Sarbatly R, Nithyanandam R (2011) A review of the antioxidant potential of medicinal plant species. Food Bioprod Process 89, 217-33.

36. Chang S-T, Wu J-H, Wang S-Y, Kang P-L, Yang N-S, Shyur L-F (2001) Antioxidant activity of extracts from 
Acacia confusa bark and heartwood. J Agr Food Chem 49, 3420-4.

37. Boonsom $\mathrm{T}$, Waranuch $\mathrm{N}$, Ingkaninan $\mathrm{K}$, Denduangboripant J, Sukrong S (2012) Molecular analysis of the genus Asparagus based on mat $\mathrm{K}$ sequences and its application to identify $A$. racemosus, a medicinally phytoestrogenic species. Fitoterapia 83, 947-53.

38. Gao T, Sun Z, Yao H, Song J, Zhu Y, Ma X, Chen S (2011) Identification of Fabaceae plants using the DNA barcode matK. Planta Med 77, 92-4.

39. Zhu S, Bai Y, Oya M, Tanaka K, Komatsu K, Maruyama T, Goda Y, Kawasaki T, et al (2011) Genetic and chemical diversity of Eleutherococcus senticosus and molecular identification of Siberian ginseng by PCR-RFLP analysis based on chloroplast trnK intron sequence. Food Chem 129, 1844-50. 